\title{
Literary Society Libraries at Muhlenberg College
}

\author{
Mr. Davidson is librarian, Muhlenberg \\ College.
}

$\mathrm{M}$

Uhlenberg College was established in 1867 to some extent as successor to two earlier Allentown institutions, the first founded in 1848 as a preparatory school, the second developing from the first as a preparatory and collegiate institution. Muhlenberg itself began by offering college, academic, preparatory, and primary programs and continued to operate a secondary school until 1939.

The first class at Muhlenberg consisted of twenty-five students in the "Collegiate Department" and 136 students in the three lower departments. During the first fortyfive years of its existence-the period of the literary society libraries - the total enrollment was quite evenly divided between collegiate and non-collegiate students. There were periods of ups and downs for each group, but the total enrollments for these forty-five years were 3,762 in the college department and 3,316 in the preparatory departments. In 1912, the last year under consideration, there was a collegiate enrollment of 132-no larger number ever having been enrolled - and a preparatory enrollment of 123 .

These figures are given to illustrate the fact that for almost its first half century at least Muhlenberg did not concentrate its educational endeavors at the collegiate level. The original charter called for "... a an Academy to consist of a primary School, a College, and such other appro- priate departments as the patrons and managers of said Institute shall find themselves able to maintain, by the name, style and title of Muhlenberg College...." The whole College was housed in one building, and there is evidence that at least occasionally members of the College faculty taught courses in the lower departments.

To what extent this lack of concentration on education at the collegiate level affected the development of an institutional library is a matter of conjecture. Certainly the rigidly prescribed courses of studies in the preparatory departments demanded no books other than textbooks in this area. It seems reasonable to assume, therefore, that the divided efforts of the institution weakened the emphasis on higher education and on the development of a library to serve the needs of higher education. By way of contrast, it is astonishing to see what the collegiate-controlled literary societies did to provide books and other reading materials for their own use.

Some credit must be given the College for its attempts at creating an institutional library. It is true that the original charter, the statutes, the several announcements and addresses made at the opening of the institution contain no mention of a library. It is also true that an early act of the College was to divide equally the Ioo books it had inherited from its predecessor and to present them to two of the literary societies, instead of using them as a nucleus for a library of its own.

However, the first two College catalogs 
( 1867 and I 868) state that a library is to be provided; the third through the fifteenth catalogs (I869-I88I) contain the following: "The building is fully provided with a Chapel, Library, Recitation, and Reading rooms, etc." Thereafter, through I904, each annual catalog contains a similar though differently worded statement, and in another part of each catalog a section entitled "Donations to the Library and Mineralogical Cabinet" is added.

The two most influential literary societies at Muhlenberg, the Euterpean and the Sophronian, were organized only seven days after the official opening of the institution in September of 1867 . Most of the "Collegiate Department" students had transferred from other colleges where they had been members of literary societies. They divided themselves by lot. "Academics" were allowed to join either group if they wished to do so, but the societies were predominantly "collegiate" in the early days and entirely so by $\mathrm{I} 89 \mathrm{I}$, although "Academics" were allowed to borrow society books thereafter. By January I 868, there were thirty-five Euterpeans and thirty-one Sophronians.

Membership in one or the other society was compulsory for many years, but there is no indication of any compulsion on the part of the College for the establishment of the societies in the first place, although they quickly became semi-official at least. Toward the end of October, I 867, the College Regulations were adopted and printed. Two of these pertain to literary societies: No. I 7 reads, "No literary or other society shall exist in the College, except by permission of the Faculty, and their approval of its Constitution"; and No. 22, "Wednesday afternoon of each week is devoted to the exercises of the Literary Societies. Students who are not members, or who are not in attendance, shall remain in their rooms during hours of study."

Although the activities of the societies were by no means confined to the building of libraries, the object of the Euterpean Society, as set forth in its constitution (Article I, Section 2) is particularly interesting: "The object of this association shall be the diffusion of liberal principles and the promotion of social, intellectual, and moral improvement of its members by the establishment of a Library, Reading Room, and so forth, and have ample power to perform such acts as may be necessary to these objects." In addition, a librarian and assistant librarian are called for, and in the bylaws five regulations governing the library are promulgated. Most interesting of these is the first, that, "The Library shall be opened on Wednesday Afternoon from I to $I \frac{1}{2}$ O'Clock and on Saturdays from 8 to $8 \frac{1}{2}$." Most significant, perhaps, is the regulation permitting books to circulate freely for two weeks, subject to renewal.

The Sophronian Society constitution does not emphasize the library as does the Euterpean, and it is at least interesting to note that the former group never had as large a library as the latter. However, the Sophronian does call for a librarian and an assistant librarian, and in the bylaws for a library committee which "... shall purchase and receive all books, voted by the Society, catalogue, and label the same within one week after their arrival; and have general supervision of the Library."

One of the Sophronian regulations puts a rather heavy burden of responsibility on the librarian and the president of the library committee. Article 9, Section 6 of the bylaws states, "The Librarian as long as he has possession of the library Alcove keys, shall be held personally responsible for any books or other property of the Society, deposited in said Alcoves, that may be stolen 
or lost; and he and the President of the Library Committee shall be together held responsible for all property of Society not deposited in said Alcoves, but placed in the Library-hall."

With such a start as to membership and constitutional authority, the two societies went to work at once to assemble collections of books, with the following results:

By January 10, I 868-four months after its organization-the Euterpean Society had 390 books in its library and \$104.50 on hand with which to buy more. In April of the same year it borrowed $\$ 200$ in order to buy additional books. By 1875 it had I,225; by 1892 it had 2,151 .

During the same period the Sophronian Society did nearly as well. By the end of the $187 \mathrm{I}$ school year it possessed 800 books, having spent nearly $\$ \mathrm{I}, 000$ in three years for books and furnishings. In 1874 , it spent \$125 for new shelving. In 1892 there were 1,700 books in the library. The society books were of excellent quality, strong in the English and American literary classics and standard works, a discriminating collection to have been assembled by undergraduate students.

A comparison of these early libraries with the College library may serve to emphasize the importance of the former. Unfortunately in none of the three accession books were entries dated; therefore year-for-year comparisons are impossible. However the College library added approximately 2,500 books in about the first twenty years while the two society libraries combined added $3,85 \mathrm{I}$ in the first twenty-five years.

In addition to trailing in quantity, the College library appears to have been even more deficient in quality - at least in those items which would appeal to or be readily useful to college students. The first 2,500 accessioned College books fall roughly into the following groups: foreign language (chiefly German, then Latin), I,200; English language other than various government publications, 800; government publications, 500. It was approximately twenty years before the first play of Shakespeare was added to the library, and that in Pope's edition. Robinson Crusoe in Arabic came long before Robinson Crusoe in English.

There is, moreover, some evidence to indicate that for more than the first twenty years of its existence the College library consisted entirely of gift books. The Faculty minutes of January 30,1889 , include a recommendation that Smith's Bible Dictionary be purchased for the College library. No entry of a like sort precedes it in any extant minutes, although many resolutions to thank library donors do. Thus, while the society libraries had been spending several thousands of dollars for books, the College had apparently spent nothing.

Another significant difference lies in the fact that for the first eleven years no books were circulated from the College library, while the societies made their books readily available for outside use.

Unfortunately there was much duplication of titles between the two society libraries, and after the first twenty-five years the College library contributed a third copy. in many instances. In perspective it seems unfortunate that some plan of cooperative acquisitions could not have been followed by the three libraries located in the same building and designed to serve a single student body of 132 students.

After the first twenty-five years the society libraries very nearly stopped growing. No definite reason can be assigned for this slackening off during the following ten years, as the societies themselves remained active and important. It is true that the College library was becoming considerably 
larger, but it continued to be the least interesting or valuable to college students. Nevertheless, during the last twenty years of their existence the Euterpean Society added only $75 \mathrm{I}$ books and the Sophronian only 745 .

In the fall of 1904 an event occurred which had a profound effect on the society libraries. The College was moved to a new location, and the three libraries, instead of being housed separately, for convenience were shelved in the same room. Although kept apart, the books became accessible to members and non-members alike, and any earlier sense of pride in possession and attainment must have been lost. For seven more years-until the end of the 1912 spring term-the libraries were maintained in this status. During the summer of 1912, with the consent of the societies, they were combined physically into a single College library. At that time the College had I3,307 books, the Euterpean Society 2,90I, the Sophronian 2,445 .

Shades of the society libraries remained for many years, however. The societies themselves continued to exist until I9I9 and contributed some books as gifts to the combined library. As late as 1924 books were accessioned in the society accession books and bore a society designation - this in order to use up the blank pages, according to the librarian!

A third "literary" society, not previously mentioned, existed at Muhlenberg for thirty-six years, from I 868 until I904. According to its constitution, Article I, "This society shall be known by the name of the Franklin Society of Muhlenberg College, its object being to furnish the members of this society with the newspapers and periodicals of the day." Membership was open to ". . . any student or instructor paying his fees and signing the constitution...." The society maintained a reading room which was ". . . open between six and eight o'clock A.M.; and between the hours of eleven A.M. and two o'clock P.M.; and from four o'clock P.M. to the ringing of the evening Chapel-bell ; except on Saturday when it shall be open the whole day."

The whole concept of this society, then, was different from that of the Euterpean and Sophronian societies. It engaged in no debates, declamations, or other literary exercises. Its constitution called for meetings only three times a year rather than weekly. Its facilities were available many hours each day, in which respect it seems more nearly to have resembled a college library today than did the libraries of the other two societies.

Perhaps unfortunately it regarded its material as ephemeral. Papers were removed from the file every Wednesday, and the second last Thursday of each session they were disposed of at public sale. There is no record of long files of periodicals being maintained nor binding being done. On the contrary, at least one title was presented to the College library when the Society was ". . . through with it," and others were sold to a professor after two weeks!

Except for the addition of certain members of the faculty, membership in the Franklin Society was of necessity composed of students who belonged to the other two literary groups. Here then, in addition to supplying most of their own books, the students of the College were supplying most of their own newspapers and periodicals, an additional financial burden on them and an additional relief for the College itself from financial responsibility. The first specific mention in the College Faculty minutes of the Franklin Society records the approval of the Society's constitution on February I 7, I 868; the second, on September 7, I 868, states, "Resolved, that the Reading-Room be committed to the care of the Franklin 
Society under the supervision of the college Librarian. Resolved, that Prof. Richards be Librarian of the Institution." In I 886 the Reading Room was "frescoed" by the Franklin Society.

It would appear that the students paid well for their society memberships. The account of one typical Euterpean member reveals that he paid that group \$28.05 during his four years in college from 1872 to 1876 . Another paid $\$ 26.60$ during his four-year stay. If these students were members of the Franklin Society also, they paid fees of \$I.00 a year in addition, not including fines. The students as a group were not wealthy, and for the sake of comparison full tuition for a year was $\$ 45.00$ at the time; board was fifty-four cents a day.

In the absence of any critical commentaries on the relationships of the College and literary societies in the early period, there can be no more than surmises as to why the business of supplying reading materials fell so largely to the societies. It has been stated that the students of 1867 had belonged to literary societies elsewhere and therefore recognized the value of them. Did these students begin their work with unnecessary enthusiasm and effectiveness? $\mathrm{Had}$ they not undertaken such ambitious programs would the College have assumed greater responsibilities itself?

On the other hand the College may have felt that the initiative and responsibility assumed by the students was a valuable exercise in itself. Library fees, which might have been levied under different circumstances, were not warranted, and that part of the society dues which went for library purposes may have been considered a reasonable substitute.

As the record stands, however, it was the students themselves, through their literary societies, who carried the burden of furnishing reading materials for their own use.

\section{Mountain Plains Library Association Loan Fund}

It is proposed that the MPLA create and finance six loan funds to be used by persons in the seven states in the MPLA area to attend accredited library schools. A qualified person may borrow up to $\$ 200$.

Policy.-The Loan Fund will be administered by a committee of three, appointed by the President of MPLA. The appointment should be for three years, and a new one to be appointed each year to provide continuity. One of the three serving a third year term will be made chairman. Applications for the loan may be made at any time, and may be sent to any member of the committee or any officer of the Association who will forward the application to the chairman of the committee. Two librarians' names must be given as references. Each recipient of a loan must sign a promissory note and state when and where he is going to library school. If he does not attend school at that time, the loan is due immediately.

The Note.-The note is to be in the custody of the treasurer of MPLA, and payments should be made to him.

Length of Loan.-The loan shall not run for more than one year after the borrower completes the period of library school stated in his application.

Interest.-The loan shall bear an interest rate of $1 \%$ per month on the unpaid balance, starting the time the borrower finishes the period in library school stated in the application.

Payments.-The loan may be paid in ten equal monthly installments, plus interest, or the balance, plus interest, may be repaid at any time. The treasurer is to send a monthly statement to anyone owing money on one of these loans. 